\title{
An Investigation of the Factors Affecting Inflation Perceptions: A Case Study on Business and Economics Undergraduate Students
}

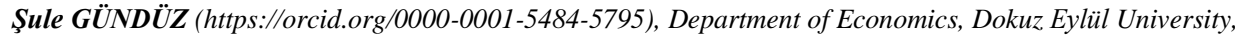
Turkey; e-mail: sule.gunduz@deu.edu.tr

Seçkin YILDIRIM (https://orcid.org/0000-0003-1292-3446), Department of Economics, Dokuz Eylül University, Turkey; e-mail: seckin.yildirim@deu.edu.tr

Mübeccel Banu DURUKAN (https://orcid.org/0000-0002-3619-2732), Department of Business Administration, Dokuz Eylül University, Turkey; e-mail: banu.durukan@deu.edu.tr

\section{Enflasyon Algısını Etkileyen Faktörler: İşletme ve İktisat Lisans Öğrencileri Üzerine Bir Çalışma}

\begin{abstract}
The aim of this study is to investigate the factors behind the inflation perceptions of undergraduate students of economics and business. Factors, such as education in economics, sociodemographic conditions, cognitive abilities, financial situation and consumption habits are investigated. The empirical evidence suggests that economics students on the average estimate a higher level of inflation than the official rate however their perceptions are closer to actual rates compared to the other students. The findings reveal that economic literacy, financial situation, gender, and the degree of trust regarding official measures of inflation, and purchase frequency of goods also influence inflation perceptions significantly.

Keywords : Inflation Perception, Monetary Policy, Behavioural Economics.

JEL Classification Codes : E31, E52, E71.

Öz

$\mathrm{Bu}$ çalışmanın amacı iktisat ve işletme lisans öğrencilerinin enflasyon algısının arkasında yatan faktörleri araştırmaktır. Bu bağlamda, ekonomi eğitimi, sosyo-demografik koşullar, bilişsel yetenekler, finansal durum ve tüketim alışkanlıkları gibi faktörlerin enflasyon algısı üzerine etkisi incelenmektedir. Ampirik bulgular ekonomi öğrencilerinin enflasyon oranını ortalamada resmi orandan daha yüksek tahmin ettiğini ancak enflasyon oranı ile ilgili algılarının diğer öğrencilere göre gerçek enflasyon oranına daha yakın olduğunu göstermektedir. Çalışmanın sonuçları ekonomik okur yazarlık, finansal durum, cinsiyet, resmi rakamları açıklayan kuruma güven ve malların satın alma sıklığının da enflasyon algısı üzerinde etkili olduğunu ortaya koymaktadır.
\end{abstract}

Anahtar Sözcükler $\quad$ : Enflasyon Algısı, Para Politikası, Davranışsal İktisat. 


\section{Introduction}

Inflation is among the most significant concerns of macroeconomics. Köse et al. (2019: 2) imply that it is one of the major economic problems in emerging markets and developing economies (EMDEs) such as Turkey ${ }^{1}$. Inflation expectations play a crucial role in monetary macroeconomic models. Pierdzioch et al. (2016: 42) and Mishkin (2000: 105) argue that monitoring inflation is especially a very important factor for countries that implement inflation targeting strategy to maintain price stability. Within the scope of this strategy, central banks aim to create an inflation anchor by announcing a numerical inflation target. Inflation targeting acts like an anchor in the formation of long-term inflation expectations, which in turn shape the economic decisions and behaviours of economic agents (Cavallo et al., 2017: 33; Gürkaynak et al., 2010: 1210). Inflation expectations have a direct impact on the consumption, saving and investment decisions of households and firms.

The credibility of central banks is a critical factor with regards to the ability to influence the inflation expectations of economic agents, as suggested by Łyziak and Paloviita (2017: 70). In that respect, to reach the inflation target, it is important that households and firms trust the central bankers and understand monetary policy strategy so as to adjust their expectations regarding wage and price-setting behaviours. Bernanke (2007), Van der Klaauw et al. (2008: 3) and Oral (2016: 43) claim inflation expectations are crucial for monetary policy and hence the achievement of price stability. Knowing this fact, central banks closely monitor inflation expectations through monthly surveys (Soybilgen \& Yazgan, 2017: 31).

Inflation perception is one of the fundamental factors behind inflation expectations that affect economic decisions. In other words, inflation perceptions feed back into expectations and, as Ashton (2012: 47) argues, they affect actual inflation. Hence, these perceptions play a fundamental role in the achievement of the targeted inflation level that is set by the central banks.

In light of the above explanations, the present study aims to contribute to the existing literature by investigating the inflation perceptions and the factors affecting inflation perceptions of undergraduate economics and business students incorporating behavioural economics insights in an emerging economy, namely Turkey. The study at hand investigates the roles of socio-demographic factors, cognitive abilities, financial situation and consumption habits on the formation of the inflation perceptions of undergraduate students, who will become a major part of the workforce and economic activity in the coming future in Turkey where inflation targeting regime has been explicitly conducted since 2006 . The

123 EMDE countries according to Köse et al. (2019: 37) are; Argentina, Bangladesh, Brazil, Chile, China, Colombia, the Arab Republic of Egypt, India, Indonesia, the Islamic Republic of Iran, Kuwait, Malaysia, Mexico, Pakistan, Peru, Poland, the Russian Federation, Saudi Arabia, South Africa, Thailand, Tunisia, Turkey, Zambia. 
Central Bank of Turkey announces the targeted level of inflation regularly in order to create an anchor which aims to influence the inflation perceptions and hence inflation expectations to actualize the target inflation rate and maintain price stability. Therefore, this study aims to provide information to the policy makers about the factors that influence business and economics students' inflation perceptions, who are expected to play a significant role in the future business environment in line with their education, taking Dokuz Eylul University Faculty of Business students as sample representatives.

The contribution of the study is twofold. Firstly, inflation is a significant issue for the developing countries. Therefore, the Turkish case constitutes an interesting investigation where high and persistent inflation has occasionally been the characteristic of the economy and among the major concerns of monetary policy makers. Even though many studies such as Oral (2016: 43), Soybilgen and Yazgan (2017: 31), Köse et al. (2019: 2-3) investigate the relationship between inflation targeting and inflation expectations in Turkey, to the best of our knowledge the studies have not analysed the factors behind inflation perceptions. The second contribution of the current study is incorporating behavioural economic factors into the analysis which tries to capture the reasons behind inflation perceptions that directly influence the inflation expectations and hence are crucial for the success of the inflation targeting strategy.

The layout of this study is as follows: Section 2 reviews the literature on inflation perceptions. The data and the method used are described in Section 3. Section 4 presents the empirical results of the study and, finally, Section 5 discusses the findings.

\section{Literature Review}

Research on inflation perceptions focuses on different aspects: i. the interaction between perceived and expected inflation rates, ii. a comparison of perceived and expected inflation with actual inflation rates, iii. the reasons behind the divergence of perceived and expected inflation from actual inflation rates, iv. the factors influencing inflation perceptions.

The first line of empirical studies investigates the interrelationship between inflation perceptions and expectations. Duffy and Lunn (2009: 140), Jonung (1981: 961) and Detmeister et al. (2016: 1) suggest that most individuals' inflation expectations are influenced by their inflation perceptions, which act like an anchor. Hayo and Neumeier (2018: 27) and Dräger (2015: 681-683) provide supporting evidence that economic agents establish their inflation expectations based on their perceptions of past inflation rates. Hence, changes in how individuals perceive inflation might trigger changes in their expectations.

The second line of research compares the perceived and expected inflation rates with the actual rates. Bryan and Venkatu (2001: 1), Duffy and Lunn (2009: 160-161) and Döhring and Mordonu (2007: 17) reveal that perceived inflation is higher than the official rate. Likewise, Duffy and Lunn (2009: 140) state that Irish consumers misperceive and overestimate price increases. Arioli et al. (2017: 64) conclude that European consumers' 
Gündüz, Ş. \& S. Yıldırım \& M.B. Durukan (2020), “An Investigation of the Factors Affecting Inflation Perceptions: A Case Study on Business and Economics Undergraduate Students”, Sosyoekonomi, Vol. 28(45), 245-263.

perceptions and expectations of inflation are much higher than actually measured rates. The third line of research investigates the reasons behind this divergence of perceived and expected inflation from actual inflation rates. Antonides (2008: 424) and Sorić and Čižmešija (2013: 16-17) suggest that socio-demographic factors and behavioural biases are among the main reasons.

Based on the findings of the aforementioned studies, a fourth line of research, which is relevant to the present study, investigates how perceptions are formed and why they differ among individuals. Heterogeneity in socio-demographic factors and social characteristics might be one of the reasons behind the variety of inflation perceptions. Del Giovane et al. (2009: 25), Detmeister et al. (2016: 2), Ranyard et al (2008: 383) and Arioli et al. (2017: 64) claim that differences in gender, income level, age and education result in different opinions about inflation.

Bryan and Venkatu (2001: 1) and Del Giovane et al. (2009: 41) state that even though both genders report a higher rate than the official rate, on average women perceive inflation to be higher than do men, which is also confirmed by Detmeister et al. (2016: 2). Together with Ranyard et al. (2008: 383), Del Giovane et al. (2009: 46), and Detmeister et al. (2016: 2) argue that both inflation perceptions and expectations are affected by income levels, concluding that financial distress causes inflation to be perceived as higher. To put it differently, the inflation perceptions of consumers depend very much on their "status quo" or "reference points" (Kahneman \& Tversky, 1979: 274). While developing inflation perceptions, economic agents intuitively and unconsciously consider their personal standpoints, like their incomes and identities, rather than analysing the prices in isolation. Another reason for the discrepancy between perceptions and actual rates is the "the fallacy of composition", as was coined by Samuelson (1951: 10). Accordingly, while evaluating price increases, individuals focus on their own purchases and assume that the inflation rate they experience is valid for the whole economy.

Other researchers focus on the role of psychological factors, such as cognitive limitations (Simon, 1990: 114), in explaining the divergence of perceived inflation rates from the actual rates. Del Giovane et al. (2009: 30) argue that these factors can be grouped into three categories. The first one is the asymmetrical perception of price increases and decreases. This cognitive bias may be attributed to loss aversion, as suggested by Kahneman and Tversky (1979: 278). In other words, the same amount of increase and decrease in inflation creates disproportionate pleasure and pain leading to higher sensitivity to the increases than to the declines. The second cognitive bias is the frequency of purchases which is closely linked to the third category, the inaccurate recall of historical prices. In real life, individuals have the tendency to remember (and recall) more recent purchases or the price increases of frequently bought products, even though these purchases may not constitute the largest part of their budgets. If individuals focus on the prices of frequently bought goods while expressing their inflation perceptions, then these perceptions are almost always biased and deviate from actual inflation since the frequency of purchases is not considered in Consumer Price Index (CPI) calculations. 
The most employed method to gather information about economic agents' perceptions on inflation is to use surveys. These surveys might be conducted via face-toface interviews or through the internet. Brachinger (2005: 999; 2008: 440) put forward an index of perceived inflation similar to the Laspeyres index, which tries to capture the increase in the overall price level from the base year to the next, using a fixed basket of goods. However, Hoffmann et al. (2006: 150) claims that Brachinger's approach fails to capture inflation perceptions accurately. Some other researchers such as Georganas et al. (2014: 157) employ controlled laboratory experiments to search for the impact of a specific factor such as frequency bias on inflation perceptions. In this study we prefer the survey method to incorporate as many factors as possible to investigate the factors behind the inflation perceptions and to overcome the limitations of using an index.

\section{Data and Methodology}

\subsection{Data}

The questionnaire developed by Del Giovane et al. (2008:23-29) has been adjusted for use with university students, since the target sample of the original questionnaire was consumers in general. The questionnaire used in the study, as presented in the Appendix 1, was conducted during the spring semester of 2018 and includes qualitative and quantitative types of questions to capture the reasons behind inflation perceptions for the period from April 2017 to April 2018 when the actual inflation rate was 10,85\% in Turkey according to Turkish Statistical Institute (2019).

\section{Table: 1}

\section{Gender and Department Distributions of Respondents}

\begin{tabular}{|c|c|c|c|c|c|c|c|c|c|c|c|}
\hline \multirow{3}{*}{ Gender } & \multicolumn{10}{|c|}{ Departments** } & \multirow{3}{*}{ Total } \\
\hline & \multicolumn{2}{|l|}{ ECO } & \multicolumn{2}{|l|}{ BUS } & \multicolumn{2}{|l|}{ IRE } & \multicolumn{2}{|l|}{ TMT } & \multicolumn{2}{|l|}{ IBT } & \\
\hline & \# of students & $\%$ & \# of students & $\%$ & \# of students & $\%$ & \# of students & $\%$ & \# of students & $\%$ & \\
\hline Male & 114 & 16,9 & 73 & 10,8 & 49 & 7,3 & 42 & 6,2 & 48 & 7,1 & 326 \\
\hline Female & 90 & 13,4 & 79 & 11,7 & 78 & 11,6 & 45 & 6,7 & 55 & 8,2 & 347 \\
\hline Total & 204 & 30,3 & 152 & 22,6 & 127 & 18,7 & 87 & 12,9 & 103 & 15,3 & $673^{*}$ \\
\hline
\end{tabular}

* 12 missing.

** ECO, BUS, IRE, TMT and IBT denote Economics, Business Administration, International Relations, Tourism Management and International Business and Trade, respectively.

The students of Dokuz Eylul University, Faculty of Business representing future economic agents, who will act as consumers and economic decision makers, have been chosen as the sample respondents. As Table 1 depicts, the respondent students are from the departments of Economics, Business Administration, Tourism Management, International Relations and International Business and Trade. Among the 1.469 students who constitute the whole population of the Faculty, 685 students took part in the survey. 10 questionnaires were void leading to a sample size of 675 . The $30,3 \%$ of the sample are economics (ECO) students whereas the students who study at the business (BUS) or business-related programs (Tourism Management-TMT and International Business and Trade-IBT) constitute the $50,8 \%$ of the total sample. The $18,7 \%$ of the sample was international relations students (IRE). The number of female students was slightly higher than the number of male students for the whole sample being almost equally distributed. The distribution of the sample, in 
terms of student departments, course years and gender, provide a robust representation of the Faculty population who come from different parts of the country.

\subsection{Methodology}

A series of ordered probit, probit and ordinary least squares (OLS) regression models have been employed in order to shed light on the relationship between inflation perceptions as dependent variables, and the aforementioned independent variables, namely sociodemographic characteristics, cognitive abilities, financial conditions and consumption/behavioural patterns of respondents. Ordered probit and probit models are convenient for the task ahead due to the binary and dichotomous natures of our dependent variables measuring qualitative inflation perceptions. On the other hand, ordinary least squares regression is suitable in the case in which our dependent variable measures quantitative inflation perceptions. Detailed explanations for our model choices will be given in the following respective sections.

In line with the main findings of the literature, in terms of what factors significantly affect inflation perceptions (Del Giovane et al., 2009: 45-46; Fritzer \& Rumler, 2015: 2021 ), the baseline forms of each model type are specified to include (i) a variable for the financial distress of consumers, (ii) a gender variable, (iii) a variable for the level of trust consumers have in official inflation measures, and (iv) a variable which specifies the consumers' level of knowledge of inflation. The baseline models provide solid foundations on which additions of further independent variables can be expected to yield healthier comparative results. The groups of independent variables for each three model types are identical. These variables are listed in Table 2.

Some of the independent variables deserve further explanation regarding their conceptual importance. Gender, the trait of being a student of economics, and financial situation form the socio-demographic characteristics of the respondents, which is, by necessity, a limited approach since all our respondents are around the same age, currently live in the same city although they come from different parts of the country, and have the similar educational attainment, ultimately handicapping the socio-demographic variance within the sample. The variables on purchase frequency, namely 'food', 'market', 'butcher', 'green', 'shop' and 'durable,' serve to measure the impact of the 'frequency bias' and are among the group of variables that account for psychological, cognitive and memory mechanisms, alongside 'awareness' of price decreases, which aims to proxy the asymmetric recognition of price movements. 'Finance', 'rent' and the dummy variable for having conducted a 'dwelling' transaction aim to measure the impact of financial distress on inflation perceptions. The variable named 'distrust' controls for whether a respondent trusts in officially announced inflation rates. 'Knowledge' variable accounts for respondents' level of understanding of the concept of inflation. Finally, the three variables 'search', 'internet' and 'card' account for the shopping behaviours of respondents. 
Gündüz, Ş. \& S. Y1ldırım \& M.B. Durukan (2020), “An Investigation of the Factors Affecting Inflation Perceptions:

A Case Study on Business and Economics Undergraduate Students", Sosyoekonomi, Vol. 28(45), 245-263.

Table: 2

Independent Variables

\begin{tabular}{|c|c|c|}
\hline $\begin{array}{l}\text { Variable } \\
\text { Name }\end{array}$ & Definition & $\begin{array}{l}\text { Expected } \\
\text { Sign }\end{array}$ \\
\hline Finance & $\begin{array}{l}\text { A dummy variable which is equal to } 1 \text { if the respondent has to, at the end of the month, incur debts or draw on current savings } \\
\text { in order to get by and } 0 \text { if they can get by without incurring debts or drawing on savings or save at least some amount at the } \\
\text { end of the month. (Question B.1) }\end{array}$ & - \\
\hline Gender & A dummy variable which is equal to 1 if the respondent is female and 0 if male. (Question S.3) & + \\
\hline Distrust & A dummy variable equal to 1 if the respondent does not trust official measures of inflation. (Question D.5) & + \\
\hline Knowledge & $\begin{array}{l}\text { A variable assuming values } 0 \text { to } 4 \text {, corresponding to the number of correct answers the respondent has given to questions } \\
\text { measuring knowledge on inflation as a concept. (Questions D.1, D.2, D.3, D.4) }\end{array}$ & - \\
\hline Food & A dummy variable equal to 1 if the respondent usually takes charge of food purchases. (Question C.2) & - \\
\hline Market & $\begin{array}{l}\text { A variable assuming values } 1 \text { to 5, depending on frequency of purchases in supermarkets/hypermarkets; (1) for "always or } \\
\text { almost always, (2) for "often", (3) for "sometimes", (4) for "never or almost never", (5) for "do not know". }\end{array}$ & - \\
\hline Butcher & $\begin{array}{l}\text { A variable assuming values } 1 \text { to 5, depending on frequency of purchases in a butcher; (1) for "always or almost always, (2) } \\
\text { for "often", (3) for "sometimes", (4) for "never or almost never", (5) for "do not know". }\end{array}$ & - \\
\hline Green & $\begin{array}{l}\text { A variable assuming values } 1 \text { to 5, depending on frequency of purchases in a greengrocer; (1) for "always or almost always, } \\
\text { (2) for "often", (3) for "sometimes", (4) for "never or almost never", (5) for "do not know". }\end{array}$ & - \\
\hline Shop & $\begin{array}{l}\text { A variable assuming values } 1 \text { to 5, depending on frequency of purchases in a small corner shop; (1) for "always or almost } \\
\text { always, (2) for "often", (3) for "sometimes", (4) for "never or almost never", (5) for "do not know". }\end{array}$ & - \\
\hline Durable & $\begin{array}{l}\text { A variable assuming values from } 0 \text { to } 3 \text { according to the number of durables purchased by the respondent in the last } 5 \text { years. } \\
\text { (Question C.7) }\end{array}$ & - \\
\hline Awareness & $\begin{array}{l}\text { A dummy variable equal to } 1 \text { if the respondent is aware of any goods whose price has fallen in the last five years, and } 0 \\
\text { otherwise. (Question A.3) }\end{array}$ & - \\
\hline Rent & $\begin{array}{l}\text { A dummy variable equal to } 1 \text { if the respondent pays rent and the rent covers more than } 30 \text { percent of the respondent's monthly } \\
\text { income. (Questions B.2, B.2a) }\end{array}$ & + \\
\hline Dwelling & $\begin{array}{l}\text { A dummy variable which is equal to } 1 \text { if the respondent has purchased, sold or has made any market research regarding } \\
\text { potential purchase or sale of a dwelling in the last five years. (Question B.3) }\end{array}$ & $+/-$ \\
\hline Search & $\begin{array}{l}\text { A dummy variable which is equal to } 1 \text { if the respondent visits more than } 3 \text { retailers before purchasing a durable good. } \\
\text { (Question C.3) }\end{array}$ & - \\
\hline Internet & $\begin{array}{l}\text { A dummy variable which is equal to } 1 \text { if the respondent often makes use of the internet as a mechanism for gathering } \\
\text { information on goods before the purchase. (Question C.12) }\end{array}$ & - \\
\hline Card & $\begin{array}{l}\text { A variable assuming values ranging from } 0 \text { to } 2 \text { depending on whether the respondent is not in possession of a cash/credit } \\
\text { card (0), or uses the card "rarely" or "never" (1) or uses the card "often" or "always" (2). (Questions C.13, C.14) }\end{array}$ & - \\
\hline ECO & $\begin{array}{l}\text { A dummy variable which is equal to } 1 \text { if the respondent is a student of the economics department and } 0 \text { if they are a student } \\
\text { of another department. (Question S.1) }\end{array}$ & - \\
\hline
\end{tabular}

A total of twenty-one regression models - seven ordered probit, seven probit and seven OLS models - were run to test the relationships between the dependent and independent variables. OLS models, which use a quantitative measure of perception as the dependent variable, are included in the analysis to confirm the findings of the other models based on qualitative measures of perception. The models estimated are as follows.

Ordered probit model: $\operatorname{Pr}\left(\right.$ QualPer $\left._{m}=\mathrm{p}\right)=\Phi\left(\beta_{1} \mathrm{X}_{1 \mathrm{~m}}+\ldots+\beta_{\mathrm{z}} \mathrm{X}_{\mathrm{zm}}\right)$

where the dependent variable QualPer $_{m}$ takes one of the values $\mathrm{p}(1,2,3)$ as a qualitative measure of the respondent $m$ 's inflation perceptions using the cumulative normal distribution function $\Phi($.$) and \mathrm{X}_{\mathrm{im}}$ represents a set of $\mathrm{z}$ characteristics (as presented in Table 2) of the respondent $m$ which affect their inflation perceptions. Ordered probit models allow for construction of dependent variables in binary forms. Since the dependent variable in this model, QualPer ${ }_{m}$, is binary in the form that it takes the value 3 if the respondents answered Question A.1 as inflation has "risen a lot", 2 if their answer was inflation has "risen moderately" and 1 if their answer was inflation has "risen slightly"; an ordered probit model is the traditional method to utilize in the case of such an analysis (Greene, 2003: 736).

Probit model: $\operatorname{Pr}\left(\right.$ ExtPer $\left._{m}=1 \mid \mathrm{X}\right)=\Phi\left(\beta_{1} X_{l m}+\ldots+\beta_{z} X_{z m}\right)$ 
where the probit regression models the probability that a respondent $m$ perceives the inflation level to have 'risen a lot' (Question A.1) using the cumulative normal distribution function $\Phi($.$) and \mathrm{X}_{\mathrm{im}}$ represents a set of $\mathrm{z}$ characteristics (as presented in Table 2) of the respondent $m$ which affect their inflation perceptions. ExtPer ${ }_{m}$ takes the value 1 if the respondent perceives the inflation level to have 'risen a lot' and 0 otherwise. Probit models are the traditional go-to models in analyses which investigate the probability of an event happening, which is, in our case, the probability of a random survey respondent perceiving the inflation rate to have risen a lot. We therefore see fit to apply a probit model in line with the literature (Greene, 2003: 736).

$$
\text { Linear Regression Model: QuanPer }{ }_{m}=\beta_{0}+\beta_{1} X_{1 m}+\ldots+\beta_{z} X_{z m}+\varepsilon
$$

where the dependent variable of the OLS model, uanPer $_{m}$, takes the numerical value of the quantitatively perceived level of inflation, based on the respondent $\mathrm{m}$ 's answer to the Question A.2. and $\mathrm{X}_{\mathrm{im}}$ represents a set of $\mathrm{z}$ characteristics (as presented in Table 2 of the respondent $m$ ) which affect their inflation perceptions. Since the dependent variable in this model is a quantitative measure of inflation perceptions, an ordinary least squares method is convenient for this analysis.

\section{Empirical Findings}

In this section, the findings of the study regarding the determinants of inflation perceptions are presented. Descriptive statistics of the independent variables are exhibited in Appendix 2. Descriptive statistics regarding the dependent variables (qualitative and quantitative inflation perceptions) are demonstrated in Table 3. Qualitative inflation perceptions of the respondents are based on their answers to Question A.1. Accordingly, $98,9 \%$ of the respondents believe that inflation has risen. $24,3 \%$ perceived this rise to be moderate and stated an average inflation rate of $24 \%$ when asked a quantitative value in Question A.2.; these observations take the value of " 0 " in the dependent variable of the probit model. $74,6 \%$ of the respondents perceived the rise to be a lot (stating the inflation rate to be $47,3 \%$ on average) and these observations take the value of " 1 " in the dependent variable of the probit model. The standard deviation (59.1) of the inflation rate for the "risen a lot" group being higher than the standard deviation (19.1) of the "risen moderately" group implies that even though some respondents stated approximately the same values for inflation rate, their perceptions varied. With respect to the ordered probit model, the dependent variable takes the value of " 1 " for 7 respondents who perceived inflation to have "risen slightly", the value of " 2 " for the 163 respondents who perceived it to have risen moderately and " 3 " for the 500 respondents who perceived it to have "risen a lot", in line with our prior explanations. None of the respondents provided an answer as "stayed about the same" or "fallen". The OLS model's dependent variable on the other hand, as explained earlier, assumes the value of the exact level of inflation perceived in each observation. 15 respondents did not provide any answer to Question A.2. 
Gündüz, Ş. \& S. Y1ldırım \& M.B. Durukan (2020), “An Investigation of the Factors Affecting Inflation Perceptions: A Case Study on Business and Economics Undergraduate Students", Sosyoekonomi, Vol. 28(45), 245-263.

Table: 3

Distribution of Qualitative and Quantitative Perceptions

\begin{tabular}{|c|c|c|c|c|c|}
\hline & \multicolumn{2}{|c|}{ Qualitative Perceptions } & \multicolumn{3}{|c|}{ Quantitative Perceptions } \\
\hline Prices have & Frequency & $\%$ & Mean & Median & Std. Dev \\
\hline fallen & 0 & 0 & - & - & - \\
\hline stayed about the same & 0 & 0 & - & - & - \\
\hline risen slightly & 7 & 1 & 7,7 & 5,0 & 4,4 \\
\hline risen moderately & 163 & 24,3 & 24,0 & 15,0 & 19,1 \\
\hline risen a lot & 500 & 74,6 & 47,3 & 40,0 & 59,1 \\
\hline Missing & 5 & 0,1 & - & - & - \\
\hline Total & 675 & 100 & 41,4 & 30,0 & 53,1 \\
\hline
\end{tabular}

As exhibited in columns 1 of Tables 4 and 5, in their baseline forms, the ordered probit and probit models yield profound evidence on the relationships between inflation perceptions and the first three core independent variables, namely finance, gender and distrust. Both of these models show a strongly positive relationship between respondents' scepticism regarding official inflation measures and their inflation perceptions, significant at $1 \%$. Gender and financial situation are also significant with their expected signs, that is, individuals who are in higher levels of financial distress report higher levels of inflation perceptions and females, in general, perceive a higher level of inflation in comparison to males.

The baseline OLS model as exhibited at Table 6 shows only the 'distrust' variable to have a significant positive relationship at $5 \%$ with inflation perceptions as expected. The coefficient of the variable implies that individuals who are sceptical about official measures report, on average, around a $10 \%$ higher perception of inflation.

In general, these results emphasize that the baseline models can be used as foundations on which to add the remaining independent variables one by one, in order to make space for a comparison between the models. Upon investigation of the augmented models in Tables 4, 5 and 6, in each of the seven ordered probit models and seven probit models, the variable 'distrust' is significant at $1 \%$ and also significant at $5 \%$ in three OLS models, at $10 \%$ in three of them, leaving only one OLS model in which the variable remains insignificant. This evidence confirms the findings by Fritzer and Rumler (2015:21) who stated that respondents who are sceptical about official inflation indicators state higher inflation perceptions. This may imply that trust in official measures of inflation plays a crucial role for central banks to be able to efficiently shape inflation perceptions and the expectations of individuals. A successful implementation of monetary policy towards the objective of lower inflation rates would require the public to perceive these rates to be accurate once they have been announced, as otherwise, the official measures and predictions would have little impact on inflation perceptions and expectations.

The second most apparent finding of the regression analyses, albeit expectedly, concerns the relationship between financial distress and inflation perceptions. Throughout the whole series of ordered probit and probit models, the outcome that students who have more difficulty getting by financially reported higher perceptions of inflation is significant and consistent in line with the findings of the literature on inflation perceptions as presented 
at Tables 4 and 5. Only in the OLS model, as seen at Table 6, the coefficient of the variable is unexpectedly insignificant.

Table: 4

\section{Ordered Probit Model Results}

\begin{tabular}{|c|c|c|c|c|c|c|c|}
\hline & $(1)$ & (2) & (3) & (4) & (5) & (6) & (7) \\
\hline & QualPer & QualPer & QualPer & QualPer & QualPer & QualPer & QualPer \\
\hline \multirow[t]{2}{*}{ Finance } & $-0,26^{* * *}$ & $-0,25 * *$ & $-0,26 * *$ & $-0,23^{*}$ & $-0,24 *$ & $-0,24 *$ & $-0,26^{*}$ \\
\hline & $(0,037)$ & $(0,042)$ & $(0,044)$ & $(0,082)$ & $(0,071)$ & $(0,073)$ & $(0,072)$ \\
\hline \multirow[t]{2}{*}{ Gender } & $0,21 * *$ & $0,20^{*}$ & $0,18^{*}$ & 0,17 & 0,18 & 0,18 & 0,17 \\
\hline & $(0,50)$ & $(0,057)$ & $(0,094)$ & $(0,134)$ & $(0,113)$ & $(0,110)$ & $(0,171)$ \\
\hline \multirow[t]{2}{*}{ Distrust } & $0,32^{* * * *}$ & $0,33 * * *$ & $0,32^{* * * *}$ & $0,33^{* * * *}$ & $0,31 * * *$ & $0,32^{* * * *}$ & 0,35 *** \\
\hline & $(0,004)$ & $(0,003)$ & $(0,005)$ & $(0,006)$ & $(0,010)$ & $(0,009)$ & $(0,007)$ \\
\hline \multirow[t]{2}{*}{ Knowledge } & $-0,06$ & $-0,06$ & $-0,08$ & $-0,10$ & $-0,07$ & $-0,07$ & $-0,11$ \\
\hline & $(0,268)$ & $(0,257)$ & $(0,141)$ & $(0,103)$ & $(0,229)$ & $(0,253)$ & $(0,104)$ \\
\hline \multirow[t]{2}{*}{ ECO } & & $-0,01$ & $-0,03$ & 0,01 & 0,03 & 0,03 & 0,08 \\
\hline & & $(0,947)$ & $(0,822)$ & $(0,916)$ & $(0,806)$ & $(0,814)$ & $(0,544)$ \\
\hline \multirow[t]{2}{*}{ Durable } & & & $0,12 * *$ & $0,12^{* * *}$ & $0,11 *$ & $0,12 * *$ & 0,11 \\
\hline & & & $(0,031)$ & $(0,037)$ & $(0,052)$ & $(0,043)$ & $(0,111)$ \\
\hline \multirow[t]{2}{*}{ Food } & & & 0,10 & 0,12 & 0,15 & 0,14 & 0,11 \\
\hline & & & $(0,380)$ & $(0,307)$ & $(0,242)$ & $(0,285)$ & $(0,413)$ \\
\hline \multirow[t]{2}{*}{ Market } & & & & 0,04 & 0,02 & 0,02 & 0,05 \\
\hline & & & & $(0,623)$ & $(0,818)$ & $(0,795)$ & $(0,599)$ \\
\hline \multirow[t]{2}{*}{ Butcher } & & & & 0,01 & 0,03 & 0,04 & 0,02 \\
\hline & & & & $(0,944)$ & $(0,730)$ & $(0,597)$ & $(0,846)$ \\
\hline \multirow[t]{2}{*}{ Green } & & & & 0,06 & 0,04 & 0,04 & 0,05 \\
\hline & & & & $(0,390)$ & $(0,549)$ & $(0,514)$ & $(0,439)$ \\
\hline \multirow[t]{2}{*}{ Shop } & & & & 0,00 & $-0,00$ & $-0,01$ & 0,02 \\
\hline & & & & $(0,973)$ & $(0,977)$ & $(0,920)$ & $(0,782)$ \\
\hline \multirow{2}{*}{ Awareness } & & & & & $-0,28$ & $-0,28$ & $-0,38$ \\
\hline & & & & & $(0,288)$ & $(0,296)$ & $(0,166)$ \\
\hline \multirow[t]{2}{*}{ Rent } & & & & & & 0,07 & 0,00 \\
\hline & & & & & & $(0,552)$ & $(0,997)$ \\
\hline \multirow[t]{2}{*}{ Dwelling } & & & & & & $-0,05$ & $-0,06$ \\
\hline & & & & & & $(0,684)$ & $(0,617)$ \\
\hline \multirow[t]{2}{*}{ Search } & & & & & & & 0,15 \\
\hline & & & & & & & $(0,224)$ \\
\hline \multirow[t]{2}{*}{ Internet } & & & & & & & 0,28 \\
\hline & & & & & & & $(0,376)$ \\
\hline \multirow[t]{2}{*}{ Card } & & & & & & & 0,03 \\
\hline & & & & & & & $(0,843)$ \\
\hline Obs. & 652 & 651 & 638 & 603 & 586 & 586 & 539 \\
\hline
\end{tabular}

The impact of gender on inflation perceptions tends to disappear as more variables are added to the baseline models in both the ordered probit (Table 4) and probit (Table 5) models, which implies that the significance of gender is less robust. Nevertheless, it can be suggested that the results comply with the evidence that females have a higher probability of perceiving a higher level of inflation than males. In the OLS models, however, as seen at Table 6, the coefficient of the variable is insignificant for all.

Regarding the impact of the frequency of purchases on inflation, the only significant finding of the models at Tables 4 and 5 is that individuals who have made more purchases of durable goods tend to report higher levels of perceived inflation. In contrast to the expected sign of this variable, we interpret the cognitive mechanism behind this result to be closely related to the fact that durable goods are usually purchased on a less frequent basis. Consumers who have made more purchases of durable goods often remember the prices of these purchases and because they may be made a relatively long time ago, the prices recalled by the individuals are often old prices, ultimately leading to higher levels of perceived 
inflation when compared with current prices. This result provides new evidence to the frequency bias already reported in the literature. On the other hand, the findings of the present study provide no evidence for the case of asymmetric recognition of price movements due to the coefficient of the variable 'awareness' being insignificant in all regressions at Tables 4,5 and 6 .

Table: 5

Factors Underlying 'High' Qualitative Inflation Perceptions (Probit Model)

\begin{tabular}{|c|c|c|c|c|c|c|c|}
\hline & (1) & (2) & (3) & (4) & (5) & (6) & (7) \\
\hline & ExtPer & ExtPer & ExtPer & ExtPer & ExtPer & ExtPer & ExtPer \\
\hline \multirow[t]{2}{*}{ Finance } & $-0,30 * *$ & $-0,30^{* * *}$ & $-0,30$ *** & $-0,28 * *$ & $-0,30$ *** & $-0,30^{* * *}$ & $-0,32 * *$ \\
\hline & $(0,016)$ & $(0,018)$ & $(0,020)$ & $(0,040)$ & $(0,031)$ & $(0,033)$ & $(0,030)$ \\
\hline \multirow{2}{*}{ Gender } & $0,19^{*}$ & $0,18^{*}$ & 0,16 & 0,14 & 0,14 & 0,14 & 0,12 \\
\hline & $(0,080)$ & $(0,091)$ & $(0,146)$ & $(0,226)$ & $(0,231)$ & $(0,229)$ & $(0,319)$ \\
\hline \multirow[t]{2}{*}{ Distrust } & $0,32 * * *$ & $0,34 * * *$ & $0,33^{* * * *}$ & $0,33 * * *$ & $0,32 * * *$ & $0,32 * * *$ & 0,36 *** \\
\hline & $(0,004)$ & $(0,003)$ & $(0,005)$ & $(0,007)$ & $(0,010)$ & $(0,009)$ & $(0,007)$ \\
\hline \multirow[t]{2}{*}{ Knowledge } & $-0,06$ & $-0,06$ & $-0,08$ & $-0,10$ & $-0,08$ & $-0,07$ & $-0,11$ \\
\hline & $(0,334)$ & $(0,313)$ & $(0,172)$ & $(0,126)$ & $(0,225)$ & $(0,248)$ & $(0,112)$ \\
\hline \multirow[t]{2}{*}{ ECO } & & 0,00 & $-0,02$ & 0,03 & 0,06 & 0,06 & 0,11 \\
\hline & & $(0,973)$ & $(0,895)$ & $(0,831)$ & $(0,619)$ & $(0,626)$ & $(0,398)$ \\
\hline \multirow[t]{2}{*}{ Durable } & & & $0,13^{* *}$ & $0,14 * *$ & $0,13 * *$ & $0,14 * *$ & $0,13^{*}$ \\
\hline & & & $(0,019)$ & $(0,023)$ & $(0,036)$ & $(0,028)$ & $(0,067)$ \\
\hline \multirow[t]{2}{*}{ Food } & & & 0,11 & 0,14 & 0,17 & 0,15 & 0,12 \\
\hline & & & $(0,340)$ & $(0,262)$ & $(0,198)$ & $(0,251)$ & $(0,367)$ \\
\hline \multirow[t]{2}{*}{ Market } & & & & 0,04 & 0,04 & 0,04 & 0,07 \\
\hline & & & & $(0,578)$ & $(0,631)$ & $(0,611)$ & $(0,450)$ \\
\hline \multirow{2}{*}{ Butcher } & & & & 0,01 & 0,04 & 0,06 & 0,04 \\
\hline & & & & $(0,902)$ & $(0,583)$ & $(0,450)$ & $(0,671)$ \\
\hline \multirow[t]{2}{*}{ Green } & & & & 0,06 & 0,04 & 0,05 & 0,06 \\
\hline & & & & $(0,343)$ & $(0,529)$ & $(0,487)$ & $(0,386)$ \\
\hline \multirow[t]{2}{*}{ Shop } & & & & $-0,02$ & $-0,02$ & $-0,02$ & $-0,00$ \\
\hline & & & & $(0,731)$ & $(0,775)$ & $(0,712)$ & $(0,942)$ \\
\hline \multirow[t]{2}{*}{ Awareness } & & & & & $-0,13$ & $-0,13$ & $-0,25$ \\
\hline & & & & & $(0,585)$ & $(0,587)$ & $(0,335)$ \\
\hline \multirow[t]{2}{*}{ Rent } & & & & & & 0,10 & 0,03 \\
\hline & & & & & & $(0,431)$ & $(0,833)$ \\
\hline \multirow[t]{2}{*}{ Dwelling } & & & & & & $-0,04$ & $-0,05$ \\
\hline & & & & & & $(0,725)$ & $(0,669)$ \\
\hline \multirow[t]{2}{*}{ Search } & & & & & & & 0,13 \\
\hline & & & & & & & $(0,305)$ \\
\hline \multirow[t]{2}{*}{ Internet only } & & & & & & & 0,07 \\
\hline & & & & & & & $(0,808)$ \\
\hline \multirow{2}{*}{ Card } & & & & & & & 0,06 \\
\hline & & & & & & & $(0,647)$ \\
\hline \multirow[t]{2}{*}{$\mathrm{C}$} & $0,76^{* * * *}$ & 0,77 **** & $0,54 * *$ & 0,26 & 0,27 & 0,17 & $-0,03$ \\
\hline & $(0,000)$ & $(0,000)$ & $(0,013)$ & $(0,520)$ & $(0,520)$ & $(0,703)$ & $(0,957)$ \\
\hline Obs. & 656 & 655 & 642 & 607 & 590 & 590 & 543 \\
\hline
\end{tabular}

The only cases where a significant impact of paying rent and dealing in dwelling transactions on inflation perceptions is detected are the sixth and seventh OLS models at Table 6 where these variables are introduced into the analysis. At a significance level of $10 \%$, it is found that students who pay rent and do so using a significant portion of their income report, on average, around a $9 \%$ higher level of perceived inflation in comparison to the students who do not pay rent or who pay rent with an insignificant portion of their income. In addition, students who have engaged in, or researched on, market information regarding purchases or sales of dwellings have reported, as exhibited at Table 6 seventh OLS model, at a significance level of $10 \%$, an approximately $7 \%$ lower level of perceived inflation than individuals who have not. A possible explanation for this impact is that these 
students and/or their families may have higher levels of income or wealth which enabled them to purchase or consider purchasing dwellings, as a result of which they may have been less sensitive to the price movements of other goods and services.

Table: 6

Factors Underlying Quantitative Inflation Perceptions (OLS Model)

\begin{tabular}{|c|c|c|c|c|c|c|c|}
\hline & (1) & (2) & (3) & (4) & (5) & (6) & (7) \\
\hline & QuanPer & QuanPer & QuanPer & QuanPer & QuanPer & QuanPer & QuanPer \\
\hline \multirow[t]{2}{*}{ Finance } & $-1,68$ & $-1,71$ & $-1,92$ & $-3,66$ & $-3,55$ & $-3,41$ & $-4,46$ \\
\hline & $(0,729)$ & $(0,723)$ & $(0,713)$ & $(0,459)$ & $(0,473)$ & $(0,499)$ & $(0,399)$ \\
\hline \multirow[t]{2}{*}{ Gender } & 0,14 & $-1,15$ & $-1,49$ & $-0,87$ & $-1,09$ & $-1,08$ & 1,22 \\
\hline & $(0,974)$ & $(0,797)$ & $(0,756)$ & $(0,863)$ & $(0,833)$ & $(0,833)$ & $(0,825)$ \\
\hline \multirow[t]{2}{*}{ Distrust } & $10,53 * *$ & $10,25 * *$ & $10,40 * *$ & $8,89^{*}$ & $8,89 *$ & $9,93 *$ & 9,22 \\
\hline & $(0,042)$ & $(0,045)$ & $(0,046)$ & $(0,071)$ & $(0,075)$ & $(0,057)$ & $(0,118)$ \\
\hline \multirow[t]{2}{*}{ Knowledge } & $-2,35$ & $-1,91$ & $-2,23$ & $-2,72$ & $-2,73$ & $-2,25$ & $-3,02 *$ \\
\hline & $(0,161)$ & $(0,236)$ & $(0,182)$ & $(0,137)$ & $(0,129)$ & $(0,189)$ & $(0,058)$ \\
\hline \multirow[t]{2}{*}{ ECO } & & $-12,5^{* * * *}$ & $-12,1$ **** & $-10,8 * * *$ & $-12,1 * * *$ & $-12,4 * * *$ & $-11,5^{* * * *}$ \\
\hline & & $(0,001)$ & $(0,002)$ & $(0,003)$ & $(0,002)$ & $(0,002)$ & $(0,006)$ \\
\hline \multirow[t]{2}{*}{ Durable } & & & $-0,20$ & 0,01 & 0,45 & 1,77 & 2,45 \\
\hline & & & $(0,909)$ & $(0,998)$ & $(0,807)$ & $(0,378)$ & $(0,294)$ \\
\hline \multirow[t]{2}{*}{ Food } & & & $-1,06$ & $-3,07$ & $-3,62$ & $-4,85$ & $-4,26$ \\
\hline & & & $(0,798)$ & $(0,523)$ & $(0,461)$ & $(0,365)$ & $(0,464)$ \\
\hline \multirow[t]{2}{*}{ Market } & & & & 0,90 & 0,70 & 0,90 & 1,53 \\
\hline & & & & $(0,755)$ & $(0,810)$ & $(0,763)$ & $(0,630)$ \\
\hline \multirow[t]{2}{*}{ Butcher } & & & & $-2,56$ & $-2,71$ & $-0,75$ & $-0,89$ \\
\hline & & & & $(0,270)$ & $(0,248)$ & $(0,690)$ & $(0,655)$ \\
\hline \multirow[t]{2}{*}{ Green } & & & & $-0,70$ & $-0,64$ & $-0,24$ & $-0,35$ \\
\hline & & & & $(0,788)$ & $(0,812)$ & $(0,927)$ & $(0,894)$ \\
\hline \multirow[t]{2}{*}{ Shop } & & & & 0,15 & 0,12 & $-0,36$ & 0,10 \\
\hline & & & & $(0,908)$ & $(0,931)$ & $(0,794)$ & $(0,940)$ \\
\hline \multirow[t]{2}{*}{ Awareness } & & & & & $-10,05$ & $-9,72$ & $-8,28$ \\
\hline & & & & & $(0,175)$ & $(0,189)$ & $(0,307)$ \\
\hline \multirow[t]{2}{*}{ Rent } & & & & & & $8,71 *$ & $9,50^{*}$ \\
\hline & & & & & & $(0,063)$ & $(0,068)$ \\
\hline \multirow[t]{2}{*}{ Dwelling } & & & & & & $-6,32$ & $-7,11 *$ \\
\hline & & & & & & $(0,122)$ & $(0,090)$ \\
\hline \multirow[t]{2}{*}{ Search } & & & & & & & $-1,64$ \\
\hline & & & & & & & $(0,782)$ \\
\hline \multirow[t]{2}{*}{ Internet } & & & & & & & $-1,79$ \\
\hline & & & & & & & $(0,785)$ \\
\hline \multirow[t]{2}{*}{ Card } & & & & & & & 3,38 \\
\hline & & & & & & & $(0,249)$ \\
\hline \multirow[t]{2}{*}{$\mathrm{C}$} & $43,0 * * *$ & $46,9 * * *$ & $48,5^{* * * *}$ & $53,3 * * *$ & $54,4 * * *$ & $44,8 * * *$ & $37,4 * * * *$ \\
\hline & $(0,000)$ & $(0,000)$ & $(0,000)$ & $(0,000)$ & $(0,000)$ & $(0,000)$ & $(0,004)$ \\
\hline Obs. & 626 & 625 & 613 & 579 & 564 & 564 & 520 \\
\hline -R-squared & 0,01 & 0,02 & 0,02 & 0,02 & 0,03 & 0,03 & 0,04 \\
\hline
\end{tabular}

Another significant finding of the OLS models is the impact of being a student of economics on perceived inflation as reported at Table 6 from second through seventh models. On average, a student of the Economics Department reported a perceived level of inflation that was around $12 \%$ lower than students of other departments. This finding is deemed logical, in that economics students are expected to be better informed on both official measures of inflation and also on the concept of inflation itself, thereby allowing their inflation perceptions to be closer to the actual rates and be less prone to overestimating inflation levels, in comparison to students from departments other than economics. Moreover, the trait of being knowledgeable on the concept of inflation influences individual perceptions of inflation, some evidence of the impact was found in the seventh OLS model. On the average, being knowledgeable leads to an around 3\% decrease in quantitative inflation perceptions. Increase in the level of knowledge narrows the gap between perceived 
and actual inflation rates. These findings suggest that economic literacy may play an important role for policy makers to achieve their monetary policy targets, namely inflation targets. More specifically, policy makers should broaden the knowledge of economic agents by providing economics education in order to successfully implement their policies. Public educational programs and trainings can be carried out by educational institutions, governmental and nongovernmental organizations as well as through social media.

Finally, confirming the findings of Del Giovane et al. (2009:45), the analyses are able to detect no significant impact of consumption and expenditure behaviours of students as depicted in Tables 4, 5 and 6. Also there exists no significant distinction between the perceived inflation levels of students who possess/use cash or credit cards during shopping, and of those who do not.

\section{Conclusion}

The inflation phenomenon is among the basic concerns of macroeconomics. The expectation of economic agents about inflation is a significant factor for effective implementation of monetary policy especially in economies where inflation targeting regime is followed. If a central bank is able to anchor economic agents' inflation expectations close to its inflation target, then it is more likely to succeed in realizing low and stable inflation. Since inflation perceptions and expectations are heavily interdependent, a precise understanding of what determines inflation perceptions is an important issue for monetary policymakers.

This study aims to analyse the roles of socio-demographic factors, cognitive abilities, financial situation and consumption habits on the formation of the inflation perceptions of undergraduate students, who will become a major part of the workforce and economic activity in the coming future in Turkey where inflation targeting regime has been explicitly conducted since 2006. It contributes to the literature by extending the analysis for Turkey to determine the factors behind inflation perceptions as well as taking behavioural factors into account.

The findings of the study reveal that besides economic literacy, the degree of trust in official measures of inflation, the level of financial distress, gender, and from a behavioural perspective, the phenomenon called the 'frequency bias', iterating that students who have made more purchases of otherwise infrequently purchased durable goods report a higher perception of inflation. In light of these results, it can be argued that the success of antiinflationary monetary policymaking in influencing economic agents' perceptions is prone to being hindered by the low level of trust in central banks and national statistical services. Moreover, economic literacy may play an important role for policy makers to achieve the inflation targets. Specifically, policy makers should broaden the knowledge of economic agents by providing economics education in order to successfully implement their policies. Public educational programs and trainings can be carried out by educational institutions, governmental and nongovernmental organizations as well as through social media. 
Gündüz, Ş. \& S. Yıldırım \& M.B. Durukan (2020), “An Investigation of the Factors Affecting Inflation Perceptions: A Case Study on Business and Economics Undergraduate Students”, Sosyoekonomi, Vol. 28(45), 245-263.

\section{References}

Antonides, G. (2008), "How is perceived inflation related to actual price changes in the European Union?", Journal of Economic Psychology, 29(4), 417-432.

Arioli, R. \& C. Bates \& H. Dieden \& I. Duca \& R. Friz \& C. Gayer \& G. Kenny \& A. Meyler \& I. Pavlova (2017), "EU consumers' quantitative inflation perceptions and expectations: an evaluation", European Central Bank Occasional Paper Series No 186 (April 2017), <https://www.ecb.europa.eu/pub/pdf/scpops/ecb.op186.en.pdf?bc91d1bc6ad64614b2d76 abbd884b1ba>, 09.10.2018.

Ashton, M.J. (2012), “'Real-Feel' Inflation: Quantitative Estimation of Inflation Perceptions”, Business Economics, 47(1), 14-26.

Bernanke, B.S. (2007), "Inflation expectations and inflation forecasting", Speech at the Monetary Economics Workshop of NBER Summer Institute, Cambridge, Massachusetts, <https://www.federalreserve.gov/newsevents/speech/bernanke20070710a.htm>, 09.10.2018.

Brachinger, H.W. (2005), "Der Euro als Teuro? Die wahrgenommene Inflation in Deutschland", Wirtschaft und Statistik, 9, 999-1013.

Brachinger, H.W. (2008), “A new index of perceived inflation: Assumptions, method, and application to Germany", Journal of Economic Psychology, 29(4), 433-457.

Bryan, M. \& G. Venkatu (2001), "The curiously different inflation perspectives of men and women", Federal Reserve Bank of Cleveland Economic Commentary, November.

Cavallo, A. \& G. Cruces \& R. Perez-Truglia (2017), "Inflation Expectations, Learning, and Supermarket Prices: Evidence from Survey Experiments", American Economic Journal: Macroeconomics, 9(3), 1-35.

Del Giovane, P. \& S. Fabiani \& R. Sabbatini (2008), “What's behind 'inflation perceptions'? A survey-based analysis of Italian consumers", Banca d'Italia, Temi di Discussione, 655, January.

Del Giovane, P. \& S. Fabiani \& R. Sabbatini (2009), "What's behind 'inflation perceptions'? A survey-based analysis of Italian consumers", Giornale degli Economisti e Annali di Economia, Nuova Serie, 68(1), 25-52.

Detmeister, A. \& D. Lebow \& E. Peneva (2016), "Inflation Perceptions and Inflation Expectations", FEDS Notes, Washington: Board of Governors of the Federal Reserve System, <https://doi.org/10.17016/2380-7172.1882>, 5.11.2017.

Döhring, B. \& A. Mordonu (2007), "What drives inflation perceptions? A dynamic panel data analysis", Directorate General Economic and Financial Affairs (DG ECFIN), European Commission, European Economy-Economic Papers, 284, 1-24.

Dräger, L. (2015), "Inflation perceptions and expectations in Sweden - Are media reports the missing link?", Oxford Bulletin of Economics and Statistics, 77(5), 681-700.

Duffy, D. \& P.D. Lunn (2009), “The Misperception of Inflation by Irish Consumers”, The Economic and Social Review, 40(2), 139-163.

Fritzer, F. \& F. Rumler (2015), "Determinants of Inflation Perceptions and Expectations: An Empirical Analysis for Austria", Monetary Policy \& the Economy, (1), 11-26.

Georganas, S. \& J.P. Healy \& N. Li (2014), "Frequency bias in consumers' perceptions' of inflation: An experimental study", European Economic Review, 67, 144-158.

Greene, W.H. (2003), Econometric Analysis, 5th ed. Upper Saddle River, Prentice Hall. 
Gürkaynak, R.S. \& A. Levin \& E. Swanson (2010), "Does inflation targeting anchor long-run inflation expectations? Evidence from the US, UK, and Sweden", Journal of the European Economic Association, 8(6), 1208-1242.

Hayo, B. \& F. Neumeier (2018), “Households' Inflation Perceptions and Expectations: Survey Evidence from New Zealand”, MAGKS Joint Discussion Paper Series, 5-2018, University of Marburg.

Hoffmann, J. \& H-A. Leifer \& A. Lorenz (2006), "Index of perceived inflation or EU consumer surveys? An assessment of Professor H.W. Brachinger's approach”, Intereconomics, 41(3), 142-150.

Jonung, L. (1981), "Perceived and Expected Rates of Inflation in Sweden", The American Economic Review, 71(5), 961-968.

Kahneman, D. \& A. Tversky (1979), "Prospect Theory: An Analysis of Decision under Risk", Econometrica, 47(2), 263-292.

Köse, M.A. \& H. Matsuoka \& U. Panizza \& D. Vorisek (2019), "Inflation Expectations: Review and Evidence", CAMA Working Paper, 29/2019, March, $<$ https://cama.crawford.anu.edu.au/sites/default/files/publication/cama_crawford_anu_ed u_au/2019-03/29_2019_kose_matsuoka_panizza_vorisek.pdf>, 25.10.2019.

Łyziak, T. \& M. Paloviita (2017), “Anchoring of inflation expectations in the euro area: Recent evidence based on survey data", European Journal of Political Economy, 46, 52-73.

Mishkin, F.S. (2000), "Inflation targeting in emerging-market countries", American Economic Review, 90(2), 105-109.

Oral, E. (2016), "Measuring Consumer Inflation Expectations in Turkey", Eastern European Business and Economics Journal, 2(1), 43-74.

Pierdzioch, C. \& M.B. Reid \& R. Gupta (2016), "Inflation forecasts and forecaster herding: Evidence from South African survey data", Journal of Behavioral and Experimental Economics, $62,42-50$.

Ranyard, R. \& F. Del Missier \& N. Bonini \& D. Duxbury \& B. Summers (2008), "Perceptions and expectations of price changes and inflation: A review and conceptual framework", Journal of Economic Psychology, 29(4), 378-400.

Samuelson, P.A. (1951), Economics: An Introductory Analysis, McGraw Hill Book Company Inc., New York.

Simon, H.A. (1990), "Bounded Rationality", in: J. Eatwell \& M. Milgate \& P. Newman (eds.), The New Palgrave: Utility and Probability, Palgrave Macmillan, London.

Sorić, P. \& M. Čižmešija (2013), "Price sentiment of Croatian consumers: The upward bias of collective memories", Drustvena Istrazivanja, 22(1), 1-21.

Soybilgen, B. \& E. Yazgan (2017), "An evaluation of inflation expectations in Turkey", Central Bank Review, 17(1), 31-38.

Turkish Statistical Institute (2019), <http://www.tuik.gov.tr/UstMenu.do?metod=temelist>, 22.04.2019.

Van Der Klaauw, W. \& W. Bruine De Bruin \& G. Topa \& S. Potter \& M. Bryan (2008), "Rethinking the Measurement of Household Inflation Expectations: Preliminary Findings", Staff Reports, 359 December, Federal Reserve Bank of New York. 


\section{Appendix: 1 - The Questionnaire}
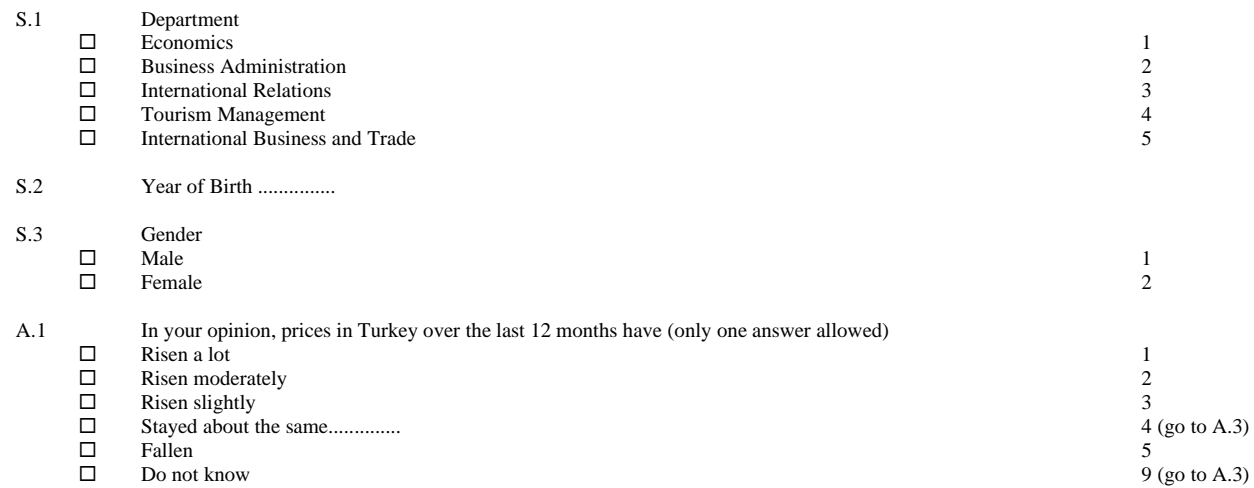

A.1 In your opinion, prices in Turkey over the last 12 months have (only one answer allowed)

$\begin{array}{ll}\square & \text { Risen a lot } \\ \square & \text { Risen moderately } \\ \square & \text { Risen slightly } \\ \square & \text { Stayed about the same } \\ \square & \text { Fallen } \\ \square & \text { Do not know }\end{array}$

A.2 Could you indicate the numerical value corresponding to your assessment? Percentage: ..........\%

A.3 In your opinion is there any good or service whose price has fallen over the last five years? (only one answer allowed) Yes

Could you give an example?

$$
\begin{array}{ll}
\square & \text { No } \\
\square & \text { Do not know/No answer }
\end{array}
$$

B.1 Considering the overall monthly income available to your household and your monthly expenditures, typically at the end of the month: (only one answer allowed)

$\begin{array}{ll}\square & \text { You must incur debts } \\ \square & \text { You must draw on your savings } \\ \square & \text { You are right on the limit } \\ \square & \text { You can save something } \\ \square & \text { You can save quite a lot } \\ \square & \text { Do not know / no answer }\end{array}$

B.2 Do you pay rent for the house/dormitory in which you live?

$$
\begin{array}{ll}
\square & \text { Yes } \\
\square & \text { No } \\
\square & \text { Do not know / no answer }
\end{array}
$$

1 2 (go to B.3) 9 (go to B.3)

B2a. In percentage terms, what share of the overall monthly income of your household is devoted to paying the rent? (only one answer allowed)

$\begin{array}{lll}\square & \text { Less than } 30 \% & 1 \\ \square & \text { Between } 30 \text { and } 50 \% & 2 \\ \square & \text { More than } 50 \% & 3 \\ \square & \text { Do not know / no answer }\end{array}$

B.3 Over the last 5 years, were you involved in a transaction to buy a house, or at least actively searching to buy or sell a house? (more than one answer allowed)

$\begin{array}{ll}\square & \text { Bought } \\ \square & \text { Sold } \\ \square & \text { Search for buying } \\ \square & \text { Search for buying } \\ \square & \text { None of the above activities } \\ \square & \text { Do not know / no answer }\end{array}$

C.2 Are you, in your household, the person who typically purchases the following products, thereby also evaluating their prices? For each type of purchase, please answer YES or NO.

Food

Cars and/or motorcycles

$\mathrm{TV}$ and electronic appliances

Personal computers

Mobile phones

Restaurant bills

$\begin{array}{ccc}\text { YES } & \text { NO } & \text { YES (with other members) } \\ 1 & 2 & 3 \\ 1 & 2 & 3 \\ 1 & 2 & 3 \\ 1 & 2 & 3 \\ 1 & 2 & 3 \\ 1 & 2 & 3\end{array}$


Gündüz, Ş. \& S. Y1ldırım \& M.B. Durukan (2020), “An Investigation of the Factors Affecting Inflation Perceptions:

A Case Study on Business and Economics Undergraduate Students”, Sosyoekonomi, Vol. 28(45), 245-263.

C.3

Let's now turn to your purchases of food products. Do you typically carry out your purchases in the same retailers?

$\square \quad$ Yes, even if more than one, but always the same

No

$\square \quad$ Do not know / no answer

C.4 Please indicate the frequency at which you carry out your food purchases in each of them, choosing between "always or almost always, often, "sometimes, "never or almost never".

(only one answer allowed for each type)

\begin{tabular}{|c|c|c|c|c|c|}
\hline & Always or almost always & Often & Sometimes & Never or almost never & Do not know \\
\hline Supermarket/Hypermarket & 1 & 2 & 3 & 4 & 5 \\
\hline Butcher & 1 & 2 & 3 & 4 & 5 \\
\hline Greengrocer & 1 & 2 & 3 & 4 & 5 \\
\hline Small corner shop & 1 & 2 & 3 & 4 & 5 \\
\hline
\end{tabular}

C.7 For each please indicate whether you have purchased one during the last 5 years. For each type of good, please answer YES or NO.

TV and electronic appliances

Personal computers

Mobile phones

$\begin{array}{cc}\text { YES } & \text { NO } \\ 1 & 2 \\ 1 & 2 \\ 1 & 2\end{array}$

C.12 Do you use the Internet to purchase or to gather information on the products you intend to purchase? (only one answer allowed)

$\begin{array}{lll}\square & \text { Often } & \\ \square & \text { Rarely } & 1 \\ \square & \text { Never } & 2 \\ \square & \text { Do not know / no answer } & 3 \\ \end{array}$

C.13 Do you have an ATM card or a credit card? (only one answer allowed)

$\square \quad$ Yes

No

C.14 (only for those reporting 1 in C13) How frequently do you use the ATM or credit card to purchase something? (only one answer

allowed)

$\square \quad$ Always

Often

Rarely

$\square \quad$ Never

$\square \quad$ Do not know / no answer

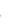

D.1 In your opinion, which one of the following statements best corresponds to the statement "inflation has been $2 \%$ in Ankara and $3 \%$ in Izmir"? (only one answer allowed)

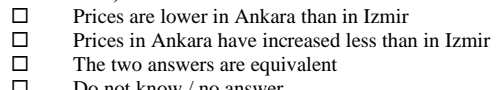

Do not know / no answer

D.2 In your opinion, which of the two following price variations corresponds to the higher increase in percentage terms? (only one answer allowed)
$\square \quad$ A price rise from 10 to $20 \mathrm{TL}$
$\square \quad$ A price rise from 100 to $150 \mathrm{TL}$
1

$\square \quad$ Do not know / no answer

D.3 In your opinion, which of the following groups of products is taken as a reference within the sample, or basket of goods, used to calculate inflation in Turkey? (only one answer allowed)
$\square \quad$ Products bought by Turkish households as a whole
$\square \quad$ Essential products
$\square \quad$ Products whose price has increased
$\square \quad$ Do not know / no answer

D.4 In your opinion, does Turkish Statistical Institute also consider dwelling purchase prices when calculating inflation? (only one answer allowed)

$\begin{array}{lll}\square & \text { Yes } & 1 \\ \square & \text { No } & 2 \\ \square & \text { Do not know / no answer } & 9\end{array}$

D.5 In your opinion, does Turkish Statistical Institute measure inflation:

(only one answer allowed)

$\begin{array}{llr}\square & \text { Very well } & 1 \\ \square & \text { Quite well } & 2 \\ \square & \text { Quite badly } & 3 \\ \square & \text { Very badly } & 4 \\ \square & \text { Do not know / no answer } & 9\end{array}$

* Questions C.1, C.4, C.5, C.6, C.8, C.9, C.10, C.11 were deleted since they were not used in the analysis. 


\section{Appendix: 2 - Descriptive Statistics on Independent Variables}

\begin{tabular}{|c|c|c|}
\hline Variables & Frequency & Percentage \\
\hline \multicolumn{3}{|l|}{ Finance } \\
\hline Incur debts or draws on savings & 485 & 72,3 \\
\hline Does not incur debts or draw on savings & 186 & 27,7 \\
\hline Total & 671 & 100,0 \\
\hline \multicolumn{3}{|l|}{ Gender } \\
\hline Female & 347 & \\
\hline Male & 326 & \\
\hline Total & 673 & 100,0 \\
\hline \multicolumn{3}{|l|}{ Distrust } \\
\hline Trusts official inflation rates & 385 & 57,8 \\
\hline Does not trust official inflation rates & 281 & 42,2 \\
\hline Total & 666 & 100,0 \\
\hline \multicolumn{3}{|l|}{ Knowledge (on the concept of inflation) } \\
\hline 0 out of 4 correct answers & 23 & 3,5 \\
\hline 1 out of 4 correct answer & 133 & 20,1 \\
\hline 2 out of 4 correct answers & 301 & 45,4 \\
\hline 3 out of 4 correct answers & 147 & 22,2 \\
\hline 4 out of 4 correct answers & 59 & 8,9 \\
\hline Total & 663 & 100,0 \\
\hline \multicolumn{3}{|l|}{ Food } \\
\hline Takes charge of purchases & 212 & 32,2 \\
\hline Does not take charge of purchases & 446 & 67,8 \\
\hline Total & 658 & 100,0 \\
\hline \multicolumn{3}{|l|}{ Market (shopping frequency) } \\
\hline Always or almost always & 9 & 1,4 \\
\hline Often & 87 & 13,1 \\
\hline Sometimes & 249 & 37,4 \\
\hline Never or almost never & 321 & 48,2 \\
\hline Do not know & 0 & 0,0 \\
\hline Total & 666 & 100,0 \\
\hline \multicolumn{3}{|l|}{ Butcher (shopping frequency) } \\
\hline Always or almost always & 24 & 3,7 \\
\hline Often & 64 & 9,9 \\
\hline Sometimes & 230 & 35,7 \\
\hline Never or almost never & 327 & 50,7 \\
\hline Do not know & 0 & 0,0 \\
\hline Total & 645 & 100,0 \\
\hline \multicolumn{3}{|l|}{ Green (shopping frequency) } \\
\hline Always or almost always & 114 & 17,4 \\
\hline Often & 242 & 36,9 \\
\hline Sometimes & 189 & 28,8 \\
\hline Never or almost never & 111 & 16,9 \\
\hline Do not know & 0 & 0,0 \\
\hline Total & 656 & 100,0 \\
\hline \multicolumn{3}{|l|}{ Shop (shopping frequency) } \\
\hline Always or almost always & 123 & 18,7 \\
\hline Often & 204 & 31,0 \\
\hline Sometimes & 193 & 29,3 \\
\hline Never or almost never & 138 & 21,0 \\
\hline Do not know & 0 & 0,0 \\
\hline Total & 658 & 100,0 \\
\hline \multicolumn{3}{|l|}{ Durable (number of purchases in the last 5 years) } \\
\hline Purchased 0 durable goods & 67 & 10,0 \\
\hline Purchased 1 durable goods & 130 & 19,3 \\
\hline Purchased 2 durable goods & 215 & 31,9 \\
\hline Purchased 3 durable goods & 261 & 38,8 \\
\hline Total & 673 & 100,0 \\
\hline \multicolumn{3}{|l|}{ Awareness } \\
\hline Aware of a good whose price decreased in the last year & 39 & 6,0 \\
\hline Not aware & 615 & 94,0 \\
\hline Total & 654 & 100,0 \\
\hline \multicolumn{3}{|l|}{ Rent } \\
\hline Pays rent over $30 \%$ of monthly income & 353 & 52,6 \\
\hline Does not pay rent & 318 & 47,4 \\
\hline Total & 671 & 100,0 \\
\hline Dwelling transaction & & \\
\hline
\end{tabular}


Gündüz, Ş. \& S. Y1ldırım \& M.B. Durukan (2020), “An Investigation of the Factors Affecting Inflation Perceptions: A Case Study on Business and Economics Undergraduate Students”, Sosyoekonomi, Vol. 28(45), 245-263.

\begin{tabular}{|c|c|c|}
\hline Bought, sold or researched dwelling & 269 & 40,1 \\
\hline No such activity & 401 & 59,9 \\
\hline Total & 670 & 100,0 \\
\hline \multicolumn{3}{|l|}{ Search } \\
\hline Visits more than 3 retailers before purchase & 369 & 60,2 \\
\hline Visits less than 3 retailers before purchase & 244 & 39,8 \\
\hline Total & 613 & 100,0 \\
\hline \multicolumn{3}{|l|}{ Internet } \\
\hline Searches the internet before purchase & 632 & 94,8 \\
\hline Does not search the internet before purchase & 35 & 5,2 \\
\hline Total & 667 & 100,0 \\
\hline \multicolumn{3}{|l|}{ Card } \\
\hline Does not have cash/credit card & 14 & 2,1 \\
\hline Uses rarely or never & 93 & 14,0 \\
\hline Uses often or always & 559 & 83,9 \\
\hline Total & 666 & 100,0 \\
\hline \multicolumn{3}{|l|}{ ECO } \\
\hline Student of Economics & 204 & 30,3 \\
\hline Student of other departments & 469 & 69,7 \\
\hline Total & 673 & 100,0 \\
\hline
\end{tabular}

* Maximum number of observations is 673. Missing observations not included. 
Gündüz, Ş. \& S. Yıldırım \& M.B. Durukan (2020), “An Investigation of the Factors Affecting Inflation Perceptions: A Case Study on Business and Economics Undergraduate Students", Sosyoekonomi, Vol. 28(45), 245-263. 